\title{
Gene expression analysis of single preimplantation bovine embryos and the consequence for developmental potential
}

\author{
NT Ruddock-D'Cruz' ${ }^{1}$ VJ Hall ${ }^{2}$, RT Tecirlioglu ${ }^{3}$ and AJ French ${ }^{4}$
}

'Centre for Reproduction and Development, Monash University, Victoria, Australia, ${ }^{2}$ Neuronal Survival Unit, Wallenberg Neuroscience Centre, Lund University, Sweden, ${ }^{3}$ Monash Immunology and Stem Cell Laboratories, Monash University, Victoria, Australia, "Stemagen Co., La Jolla, California, USA.

Preimplantation embryo development typically involves sequential morphological events connecting embryonic cleavage, morula compaction and blastocyst formation, and occurs in parallel with transcriptional regulation, specifically, the maternal to embryonic transition. The underlying homeostatic and metabolic mechanisms governing embryo development are influenced by both genetic and epigenetic factors that respond to environmental stimuli and may impact development during later gestational and fetal growth. There is a renewed interest in the identification and characterization of developmentally important genes during embryonic and fetal development. Perturbations in gene expression, resulting from environmental conditions, can have serious consequences on further embryonic development, homeostasis and disease pathogenesis. The bovine embryo is, however, capable of tolerating and adapting to a wide range of conditions, although little is known of the molecular fingerprint required for oocyte maturation, fertilization and development to term. The genomic revolution united with promising new technologies offer greater opportunity to elucidate the mechanisms behind this well-orchestrated biological process. This paper reviews the current literature on gene expression in the bovine embryo with reference to environmental interference and the development of new technologies to observe this biological process. Defining the difference in molecular signalling between in vivo and in vitro systems will undoubtedly improve the safety and efficiency of assisted reproductive technologies. The future challenge is to devise culture conditions that mimic the changing environment required by developing embryos to allow the correct temporal and spatial expression of a cohort of developmental genes in a manner similar to that seen in vivo. 


\section{Introduction}

The initiation of mammalian embryogenesis is regulated by a complex network involving the oocyte genome, transcriptome and proteome. In the absence of new transcription (Davidson 1986), completion of the first meiotic and mitotic cell cycles, gamete reprogramming (oocyte and sperm) and the maternal to embryonic transition rely on transcripts and proteins made during oocyte growth, as well as signal transduction events associated with maturation, ovulation and fertilization (Knowles et al. 2003). During preimplantation development in the mouse, an estimated 15,700 genes are expressed (Stanton et al. 2003), and it is likely that a similar number will be expressed in other mammalian species. This preimplantation period culminates in a synchronous and intricate discourse between the embryo and the receptive uterus, resulting in implantation and the pathway to further embryonic development (Wang \& Dey 2006).

In vitro production (IVP) technologies provide an alternative source of oocytes and embryos for both research and routine embryo transfer. Historically, IVP success has been primarily gauged on the morphological assessment of the preimplantation embryo. However, while the true developmental competence of any given embryo is a continuum that proceeds throughout its lifecycle, the attainment of full term development is a critical first milestone. This process particularly in a uniparous animal, such as the bovine, is restricted by the long gestational interval and the reliance on intensive recipient management programs, which requires significant capital investment. The relevance is no more apparent then when IVP embryos upon transfer to recipients show similar implantation rates when compared to in vivo embryos but then undergo significant embryonic and fetal losses (Reichenbach etal. 1992). A proportion (up to $30 \%$ ) of the surviving animals al so show increased birth weight and other anatomical abnormalities that have been described as the large offspring syndrome (Holm et al. 1996; Young et al. 1998; Renard et al. 1999; Niemann \& Wrenzycki 2000; Sinclair et al. 2000). While bovine preimplantation embryos appear capable of tolerating and adapting to wide ranging environment stimuli, a relative short exposure to sub-optimal in vitro conditions can initiate a range of downstream consequences (Wrenzycki et al, 2004).

The development of expression analysis techniques to examine the cohort of essential and developmentally important genes during early mammalian development provides a useful method to assess the normality of embryo development and to allow in vitro culture and assisted reproductive technologies to be examined and improved without the requirement for extensive in vivo testing. The interplay between the effect of microenvironment modifications and epigenetic alternations at early stages of development suggest that limited in vivo testing will still be required and not suppressed from future animal studies.

The consequence of temporal or spatial and qualitative or quantitative shifts in gene expression patterns can influence the well-orchestrated events controlling resumption of meiosis, initiation of embryo cleavage, maternal to embryonic transition, and cellular differentiation during and well beyond blastocyst formation.

What is becoming increasingly apparent is that the intrinsic quality of the oocyte plays a key factor in the overall success of these events (Lonergan et al. 2003a). However, the molecular fingerprint of an oocyte that is capable of undergoing maturation, fertilization and supporting development to term is virtually unknown.

Defining this profile will likely require comparative gene expression studies involving single embryo analyses, to account for the variability between embryos, with groups of embryos in the same environment where the outcome is to increase the mean behaviour of the group. It would appear however that many of the genes analysed (see Table 1) show consistent expression patterns as a consequence of environmental conditions in both the single and pooled embryo studies. Modifications to culture conditions would necessitate a balance to the envi- 
Gene expression in preimplantation bovine embryos

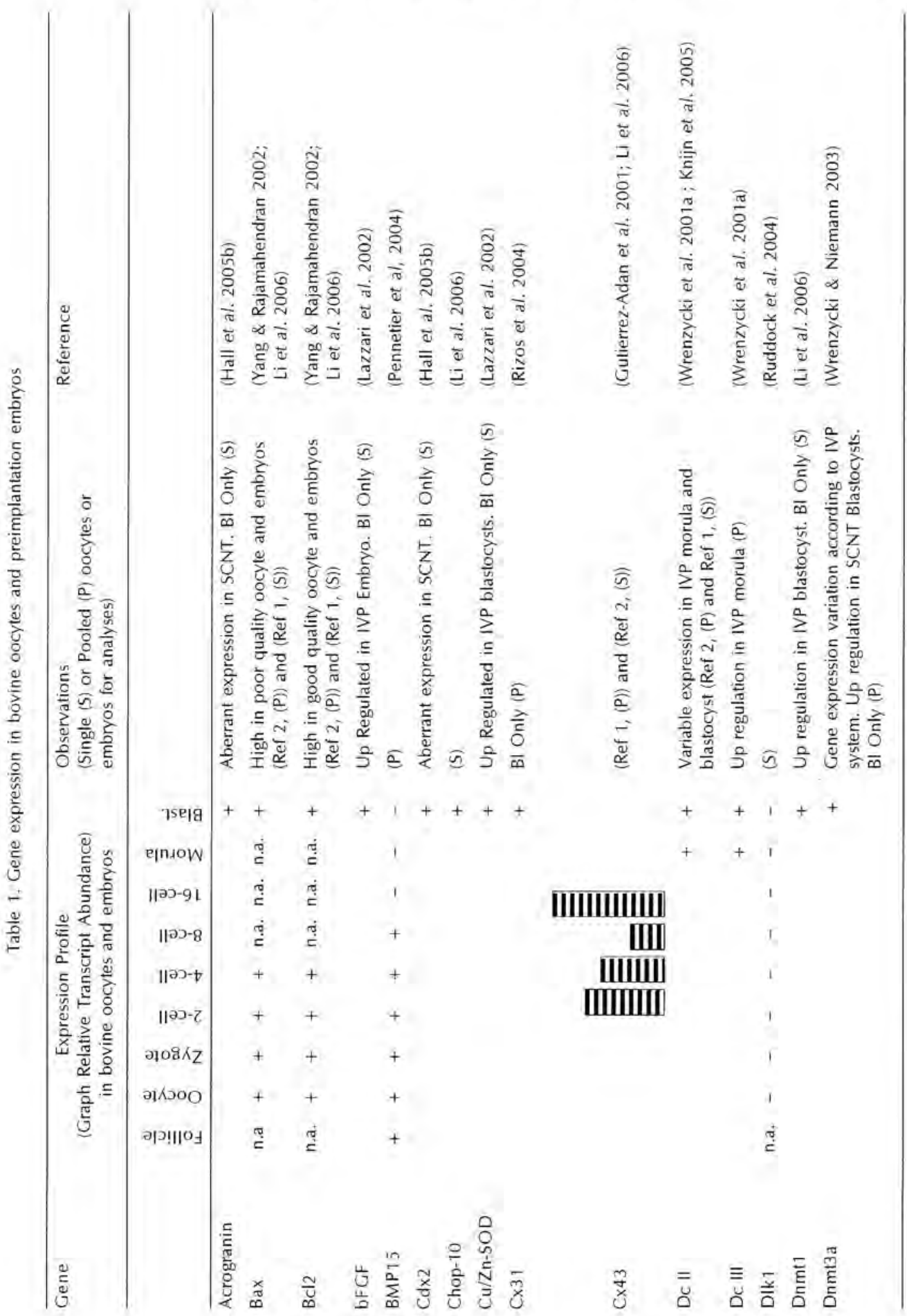




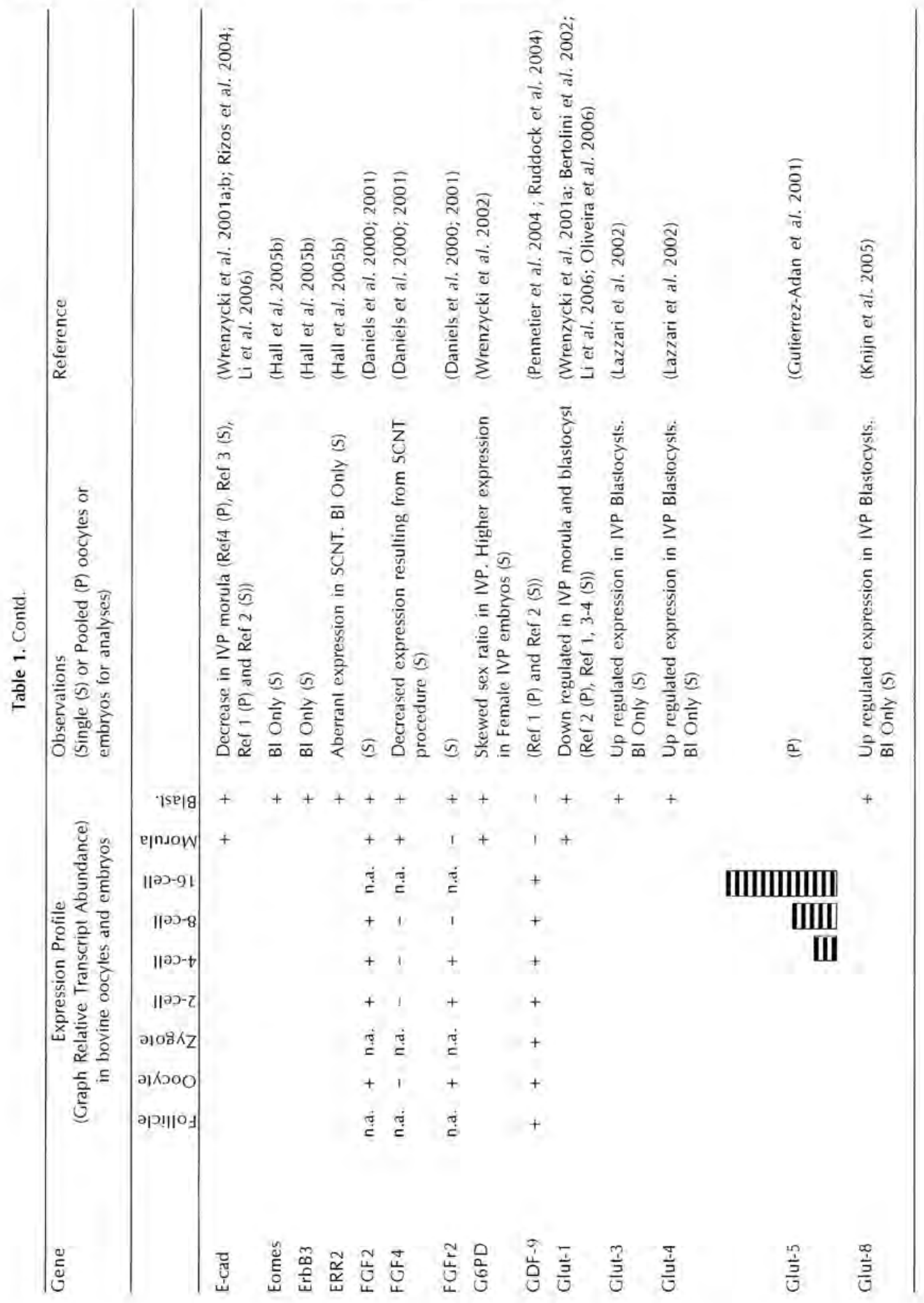




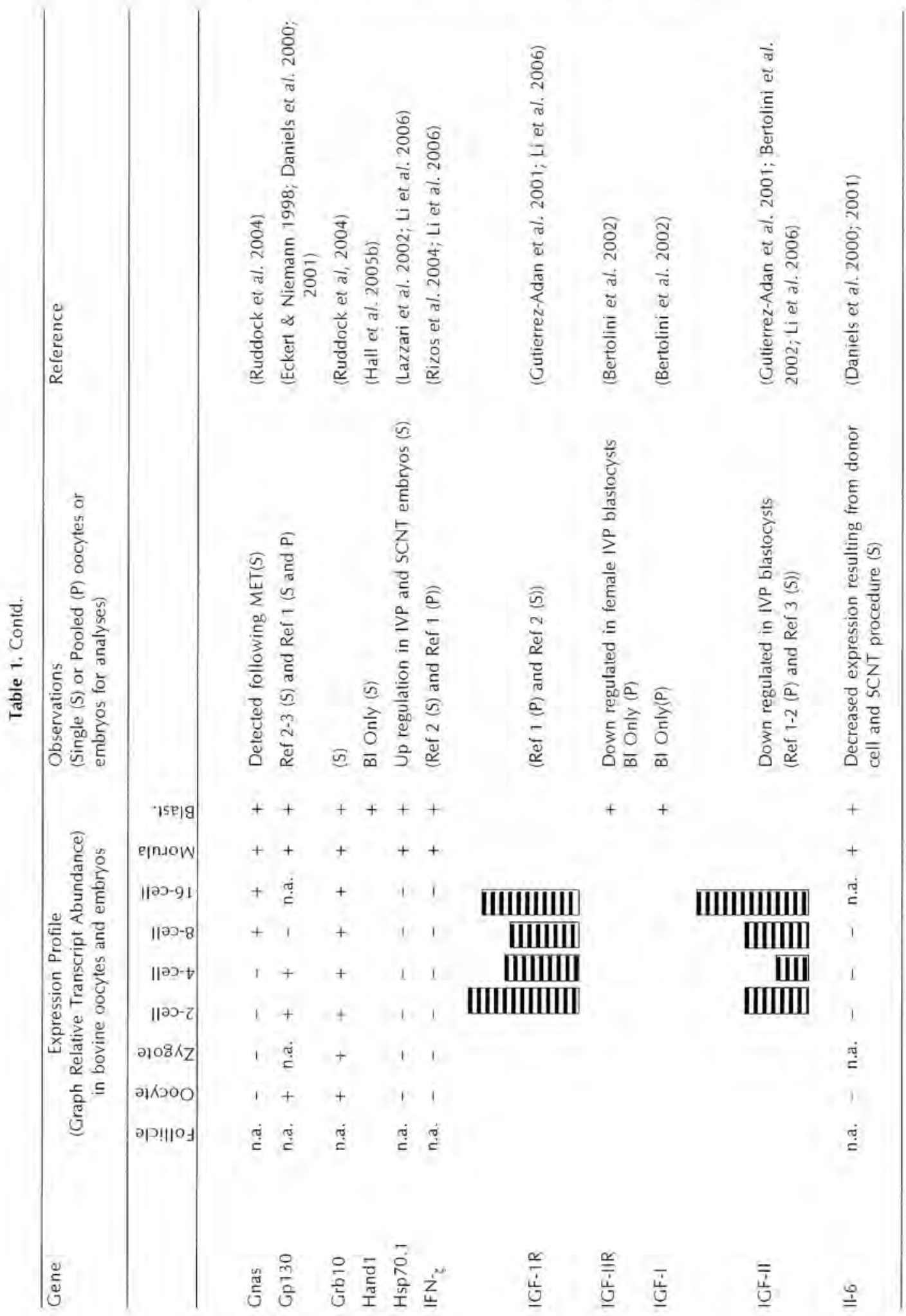




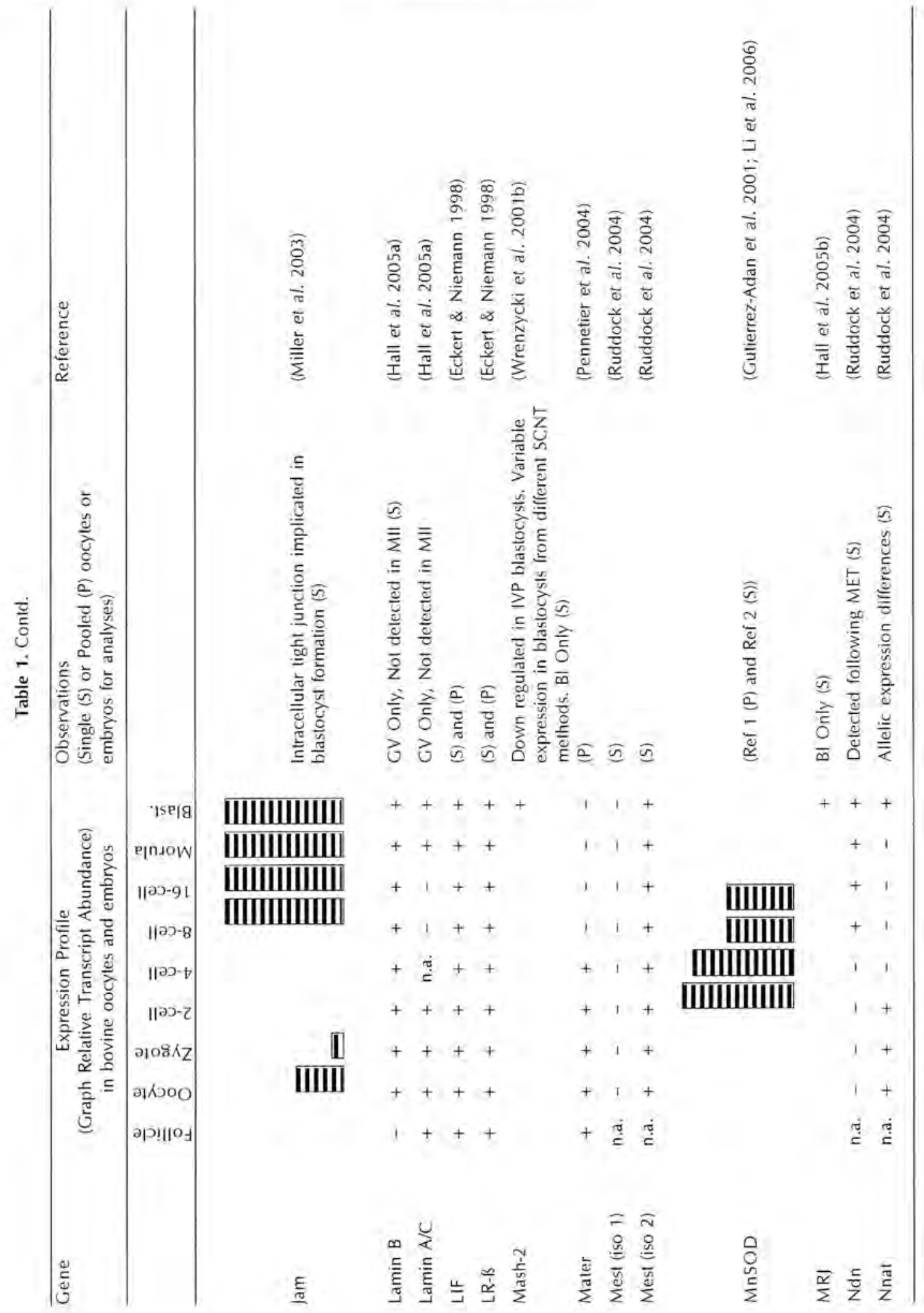




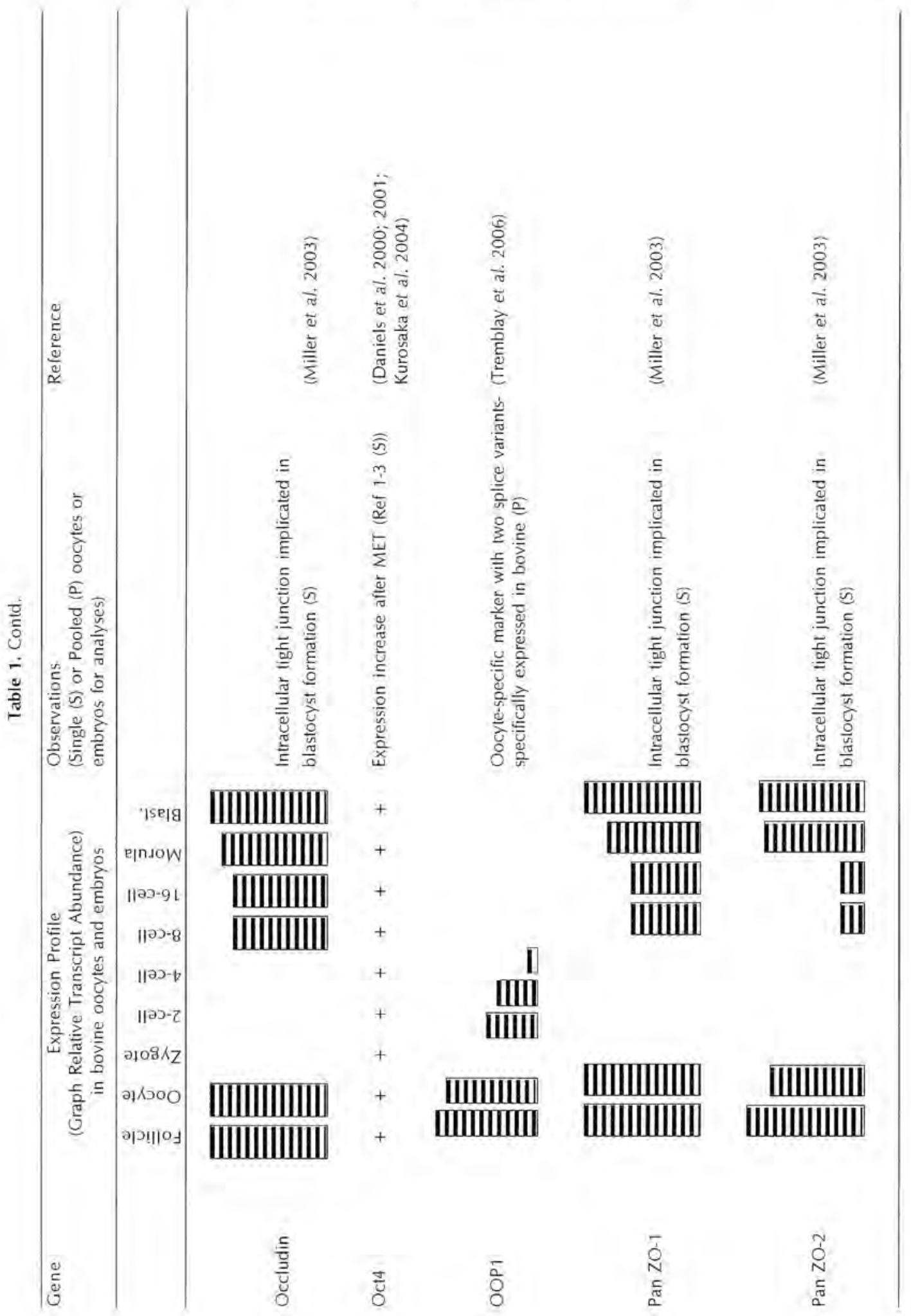




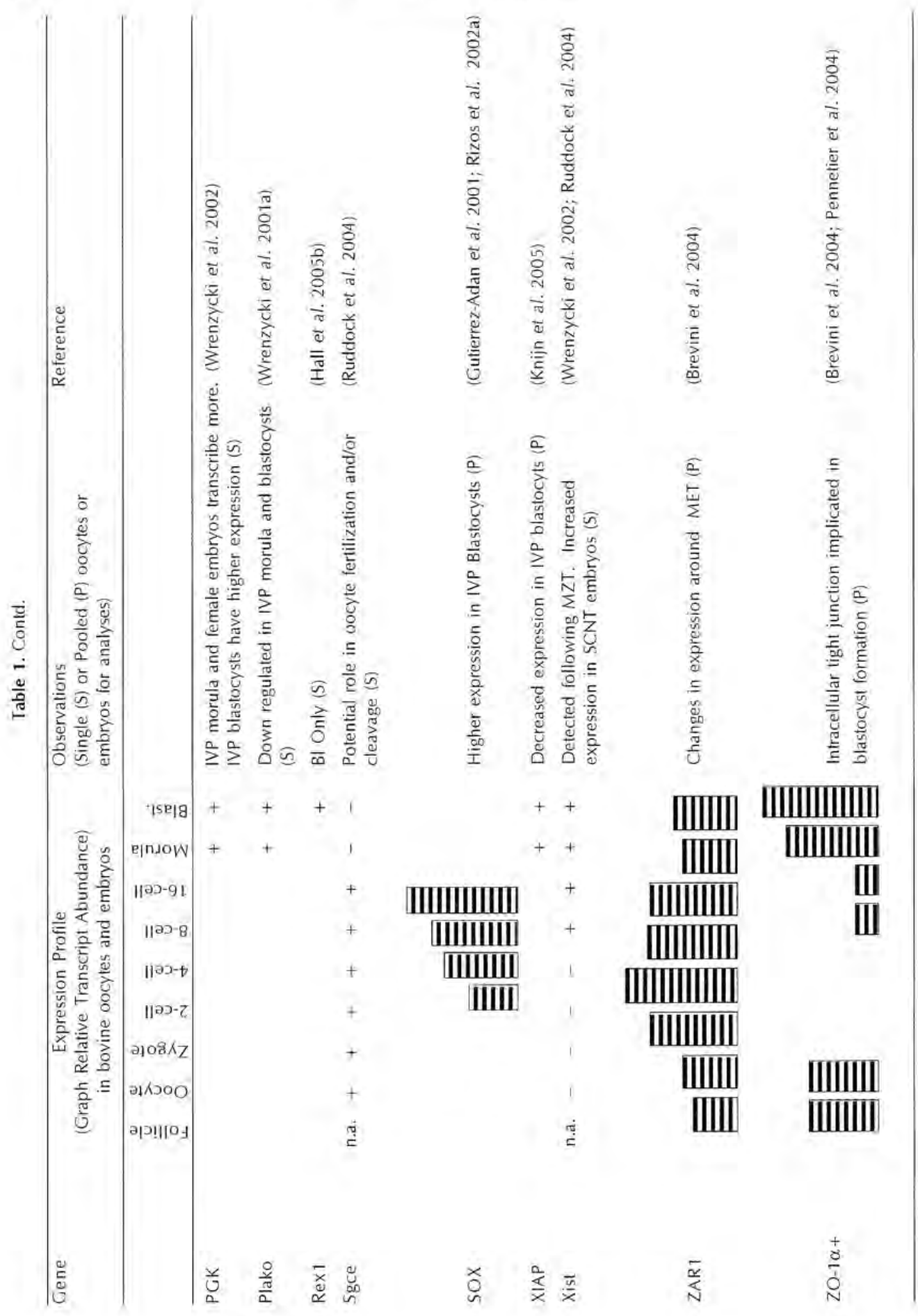




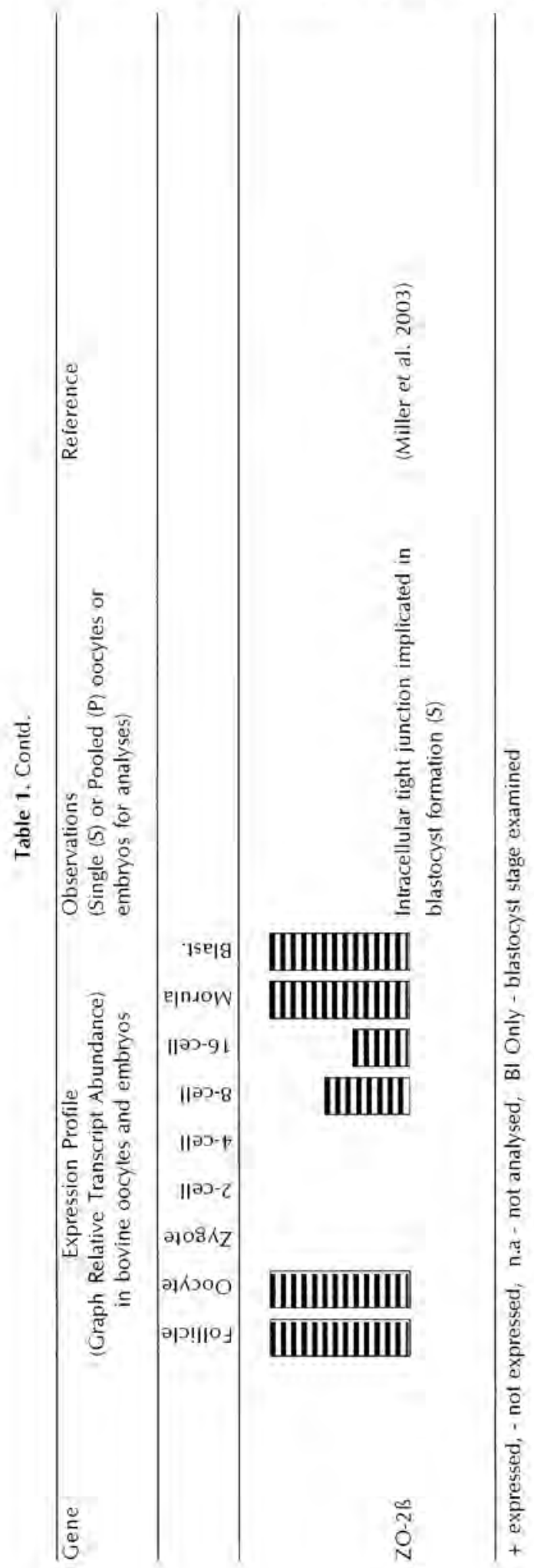


ronmental response in the individual embryo against those required for a group of embryos, that's even if correlations between morphological data and gene expression profiling are to be established. Another way to discern this variability would be to analyse gene expression of blastomeres following embryo biopsy. These analyses could be used to modify culture conditions to the single embryo according to how it responds to the environment, although the variability of gene expression between individual (or few) blastomeres is not known.

The continual development of highly sensitive techniques will enable the quantitative profiling of transcriptomes and proteomes, which are necessary to regulate and coordinate events from folliculogenesis to early embryo development and are vital to improving the efficiency of in vitro production systems (IVP) and assisted reproductive technologies. To date, research has focussed on embryonic cleavage rates (Lonergan et al. 2000; Ward et al. 2001; Comizzoli et al. 2003; Holm et al. 2003), developmental arrest (Yang \& Rajamahendran 2002), developmental competence of in vitro produced (IVP) embryos (Thompson 1997; Holm \& Callesen 1998; Enright et al. 2000), embryo manipulation (Wrenzycki et al. 2001b), culture (Wrenzycki et al. 2001a) and metabolism (Khurana \& Niemann 2000; Thompson 2000), embryo genomic activation (De Sousa et al. 1998a; Memili \& First 2000), embryo sex (Avery et al. 1992; Xu et al. 1992; Gutierrez-Adan et al. 2001), oocyte quality (Lonergan et al. 2003a), methylation status (Bourc'his et al. 2001), protein synthesis (De Sousa et al. 1998b), species differences (Wrenzycki etal. 2002), transcript abundance (Watson et al. 2000) and the functional organization of the nucleus and nucleolus (remodelling and reprogramming) (Hall etal. 2005a; Corcoran et al. 2006).

The degree to which embryo culture or manipulation influences gene expression and the downstream consequences are beginning to be revealed. This review will briefly examine gene expression studies in the bovine preimplantation embryo and the development of new methodologies to elucidate optimal conditions for improving the developmental competence of embryos generated from a variety of IVP systems.

\section{In-Vitro production in the bovine}

Despite ongoing improvements, the full potential of the IVP production system remains hampered by the overall quality of the embryo when compared to those derived in vivo. This is graphically demonstrated in Fig. 1 where embryo viability until weaning from in vivo and in vitro production systems are shown from this group over a 5 year period (2000-2005).

Differences between in vivo and in vitro derived embryos have been reviewed extensively (Thompson 1997; Enright etal. 2000; Niemann \& Wrenzycki 2000; Lonergan et al. 2003a) and the disparity between in vitro and in vivo embryos can be categorized to either the proportion that reach the blastocyst stage of development or survival following embryo transfer. Around $35 \%$ of in vitro matured and fertilized (IVM/IVF) oocytes reach the blastocyst stage and around $40 \%$ survive to term following transfer when contrasted with over $70 \%$ and $60 \%$ for the in vivo counterparts, respectively (Thompson 1997; Holm \& Callesen 1998). Manipulation of IVP embryos for the purpose of Somatic Cell Nuclear Transfer (SCNT) reduces the embryo viability even further (Wrenzycki et al. 2004).

The source of variation has been attributed to a variety of causes including the processes of in vitro maturation, site of and effect (quality) of sperm at fertilization, chromosome imbalance, polyspermy, variation in pronuclei formation, incorrect morula compaction/ blastocyst formation and sensitivity to cooling and freezing due to elevated lipid content (Thompson 1997; Holm \& Callesen 1998; Rizos et al. 2002b). 


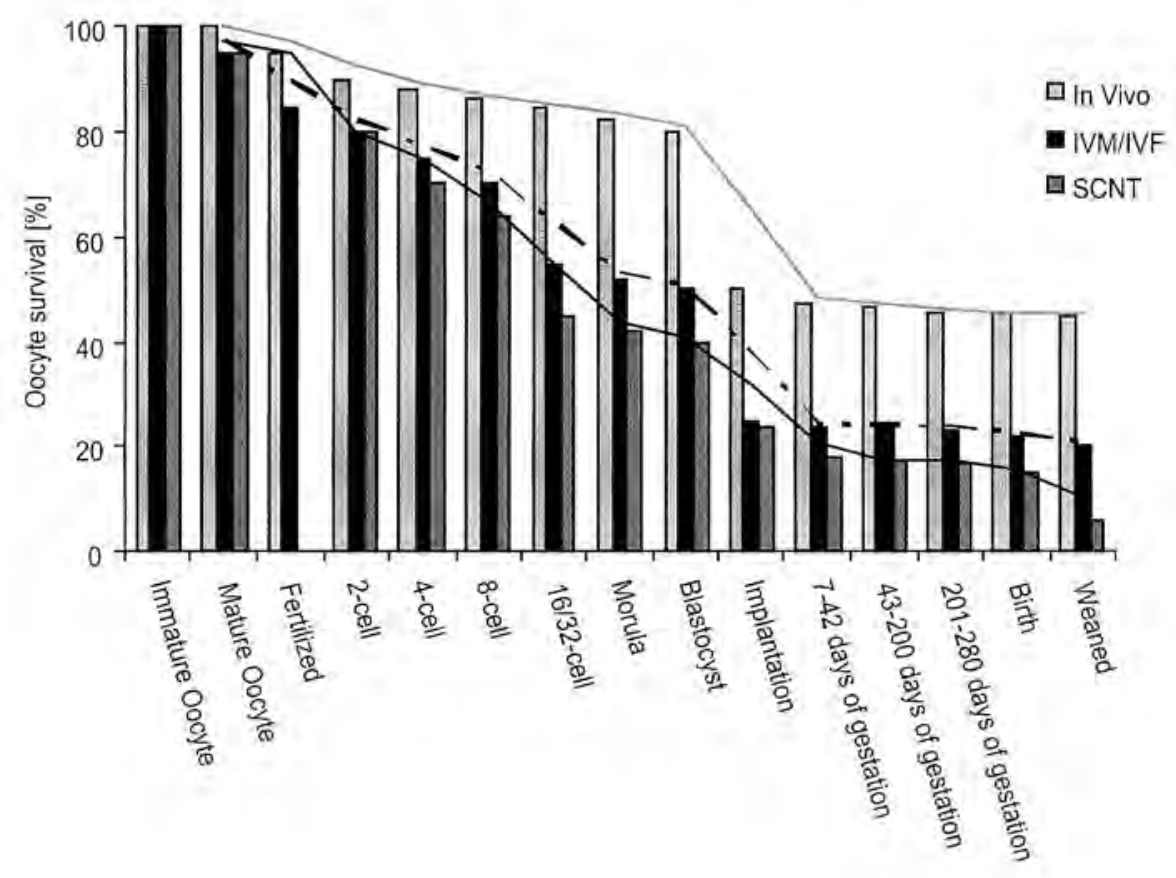

Fig. 1: The developmental competence of bovine embryos derived from In Vivo and in Vitro production (IVMIVF and SCNT) systems.

\section{Gene expression analysis in bovine oocytes and embryos}

A variety of methods are available for investigating gene expression (see below) and their sensitivity can detect qualitative and quantitative changes to transcriptional regulation during oocyte growth, maturation and embryonic development. Data from these analyses has established molecular expression profiles that may be a more accurate indicator of developmental competence when compared to morphological and blastocyst development observations (Leibfried \& First 1979; de Loos et al. 1992). The morphological classification and grading of bovine embryos (Lindner \& Wright 1983) with minor modifications (Hasler 2001), and subsequently adopted by the International Embryo Transfer (www.iets.org), is the standard to which all embryos are currently described. This practice is used extensively in both research and commercial activities (Thompson 1997; Holm \& Callesen 1998; Hyttel 2001). However it has also become increasingly apparent, particularly with the development of SCNT, that morphological data does not correlate solely with developmental competence (see Fig. 1). To battle this discrepancy, much research has recently focused on gene expression profiling in individual oocytes and embryos.

The literature precludes that over 100 genes to date have been associated with developmentally important processes in bovine preimplantation embryos from in vivo, in vitro produced, such as genes involved in compaction/cavitation, metabolism, transcription/translation, DNA methylation and histone modification, oxidative stress, response to or production of growth factors, cytokine signalling, cell cycle regulation and apoptosis. The development of SCNT 
technology adds a further level of complexity to gene expression studies where the interrelationship between incomplete somatic cell reprogramming and environmental constraints imposed by the in vitro production system need to be distinguished.

These categories of genes have been evaluated in bovine preimplantation embryos from in vivo, in vitro produced and SCNT embryos, for reviews see (Corcoran et al. 2005; Niemann \& Wrenzycki 2000; Lonergan et al. 2001; 2006; Niemann et al. 2002; Wrenzycki et al. 2004; Wrenzycki et al. 2005a;b). Many genes in IVP (and SCNT) embryos have displayed aberrant expression patterns compared with their in vivo counterparts. Both genetic and epigenetic mechanisms (methylation and histone modifications) are thought to be involved in the differences in gene expression, regardless of the fact that the developing embryo appears capable of enduring substantial dysregulation of both imprinted and non-imprinted genes (Humpherys et al. 2001; Reik et al. 2001). There are many steps associated with the IVP system including maturation, fertilization, and culture and in addition to this, various manipulations are undertaken for the production of SCNT embryos, all of which have the potential to further alter gene expression patterns in the developing embryo. These noted alterations in gene expression have been associated with the type of medium (maturation, fertilization and culture) and various additive components (growth factors, serum, etc). Interestingly, epigenetic modifications seem more prevalent in imprinted genes (Blondin et al. 2000; Ruddock et al. 2004). Many of these differences are clearly established after 1 day of culture, underling the sequential interactions between the environment and gene expression (Rizos et al. 2002a; b; 2003; Lonergan et al. 2003b). Embryo manipulations involved in the production of SCNT embryos have also resulted in varied gene expression patterns and may be associated with oxidative stress, impaired trophoblastic function, DNA methylation and X chromosome inactivation (Wrenzycki et al. 2004). The establishment of diagnostic techniques using these predictive values of aberrantly expressed genes as markers for embryo qual ity and viability is a critical step towards improving the efficiency of each system. One of the first applications of a limited microarray in the bovine showed 18 genes from a subset of intermediate-filament protein, metabolic, lysosomal-related, stress related and major histocompatibility complex class I were differentially expressed between IVF and SCNT blastocysts. (Gutierrez-Adan et al. 2001).

A summary of genes detected in single and pooled bovine oocyte /embryo samples is provided in Table 1. However while a considerable body of work has been amassed on the expression of specific genes and the role of genetic and epigenetic reprogramming, there is a need for greater understanding of the relationships between altered phenotypes, changes in both genetic code and epigenetic patterns within the genome, and alterations in mRNA or protein expression profiles and the downstream consequence for embryos generated from a variety of IVP manipulations. Direct interventions are now required to modify specific epigenetic characteristics to correlate with the biological processes associated with developmental competence, including the correct mRNA and protein expression profiles (Lazzari et al. 2002; FernandezGonzalez et al. 2004; Farin et al. 2006).

Gene expression as an indicator of developmental competence

A number of studies have shown similar rates of ATP production, glucose metabolism, pyruvate uptake and utilization between in vivo and in vitro produced embryos (Thompson 1997; 2000). However, lower total cell counts in the blastocyst and skewed ratios between inner cell mass and trophectoderm cells in IVP embryos highlight that significant developmental differences exist, which may be reflected at the molecular and cellular level. Gene expression comparisons between in vivo, in vitro and SCNT embryos have identified a number of genes associated 
with developmental competence. These include the relative abundance of transcripts encoding the $\alpha 1$ subunit of $\mathrm{Na} 1 / \mathrm{K} 1$-ATPase (De Sousa et al. 1998c), impaired cavitation and blastocyst formation induced by a decrease in expression of connexin (Cx43) in the IVP blastocyst (Rizos et al. 2002a); absence of FGF4 expression in SCNT blastocysts (Daniels et al. 2000; 2001), altered expression of lamin $\mathrm{A} / \mathrm{C}$ and $\mathrm{B}$ following fusion and early cleavage that was restored by morula stage in SCNT embryos when compared to IVF (Hall et al. 2005a). The developmental competence of oocytes and embryos is influenced by the high expression of $\mathrm{BCl}-2$ gene (antiapoptotic) and low expression of the Bax gene (pro-apoptotic), with the ratio of $\mathrm{BCl}-2$ to $\mathrm{Bax}$ expression considered a marker of embryo survival (Yang \& Rajamahendran 2002). A recent study examined 16 candidate genes associated with rapid cleavage in bovine two-cell embryos, three genes (YEAF, IDH, H2A) were differentially expressed in the early cleaving embryo and have the potential to be markers of developmental competence (Dode et al. 2006).

The majority of these studies report only steady state mRNA levels in gene expression pathways; however, RNA biogenesis is a central multi-step process that must balance message fidelity against steady-state levels of the mature RNA. An equally important area in the regulation of gene expression in mammals is the role of transcription turnover (Milligan et al. 2002). However, relatively little is known of the consequence of environmental conditions to affect transcription turnover and mRNA half-life leading to altered gene expression pathways in the embryo. Few studies, in this under investigated area, show altered gene expression levels in the embryo are due to changes in transcriptional activity.

\section{Gene expression analysis strategies and DNA amplification}

A variety of methods which are suitable for detecting gene transcription in preimplantation embryos are provided in Table 2. Conventionally, methods for detecting gene transcripts have included Northern Blotting, In Situ hybridization and RNAse Protection Assay. Limitations include low overall sensitivity and the need for a high complementary DNA (CDNA) copy number for successful analysis. Given the relative scarcity of mammalian preimplantation embryos and the requirement to pool (100) embryos for sufficient RNA, that is not applicable for analyses of rare constructs or for quantitative measurement in the individual embryo (Lechniak 2002).

\section{Polymerase chain reaction}

In contrast, the development of RT-PCR has enabled the detection of mRNAs from low yields of RNA obtained from single embryos (Bustin et al. 2005). However, the requirement to reverse transcribe RNA into CDNA is influenced by a number of variables and even a small shift in amplification efficiency may lead to exponential differences in the final PCR product (Gilliland et al. 1990; Nicoletti \& Sassy-Prigent 1996; Lechniak 2002).

The development of competitive (Auboeuf \& Vidal 1997) and semi-quantitative, non-competitive RT-PCR (Saric \& Sydney 1997) strategies have addressed variability in amplification efficiency. The first involves simultaneous co-amplification of target RNA with added exogenous synthetic RNA that competes with available reagents and primers. The constant ratio between the two types of RNA allows the initial concentration (quantitation) of target RNA to be determined. PCR products are distinguished by small deletions, modifications to restriction sites or the addition of unrelated motifs to the synthetic RNA (Nicoletti \& Sassy-Prigent 1996). The second involves co-amplification of the target RNA and unaffected endogenous (GAPDH, B-actin, rRNA) or exogenous rabbit (B-globulin) RNA using separate primers. Amplification in 


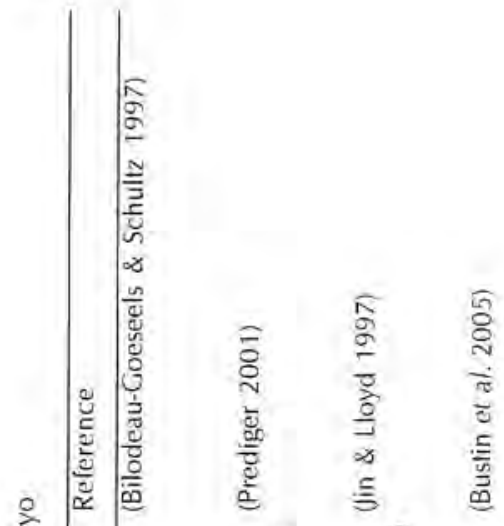

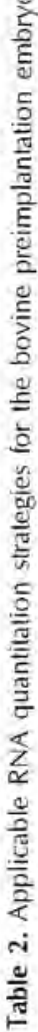

की

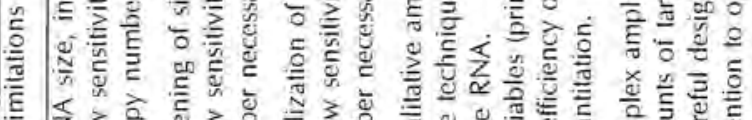

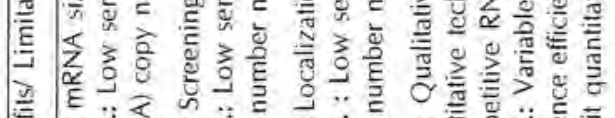

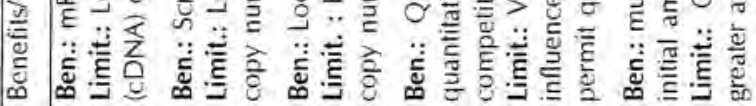

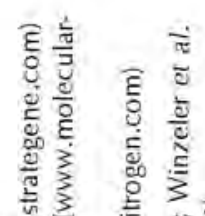

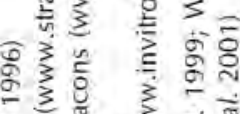

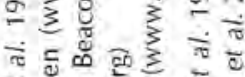

¿

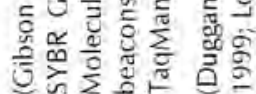

$\overline{0}$

气 ํㅡㄹ

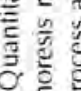

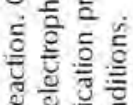

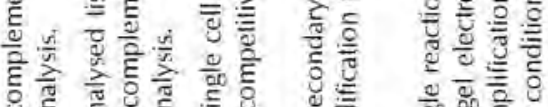

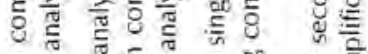

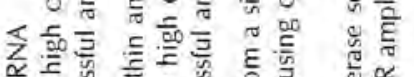
ज䟲员

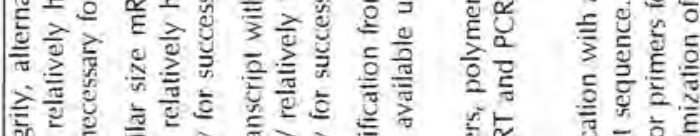

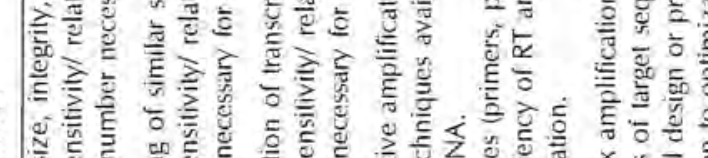

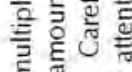

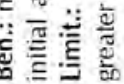

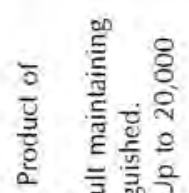

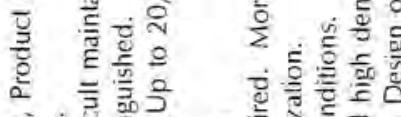

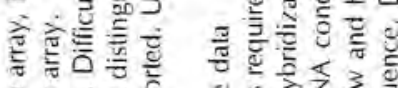

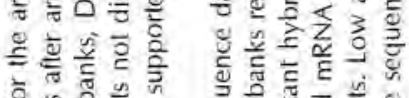

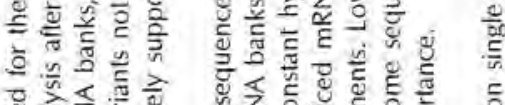

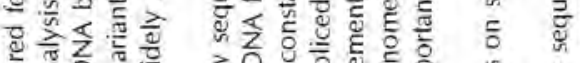

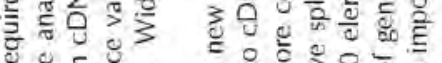
ฏ की

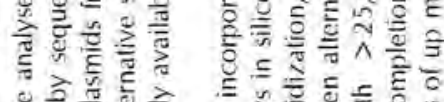

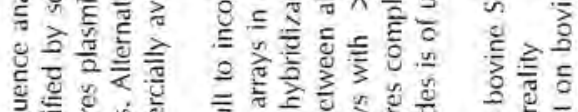

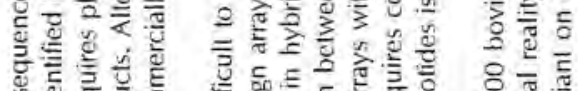

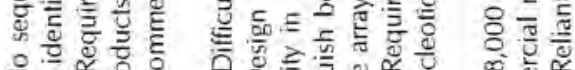

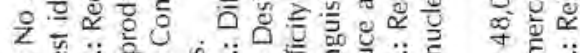

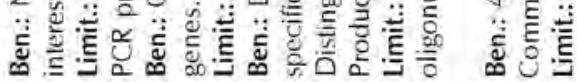


the linear range for the two primers allows the target RNA PCR products to be normalized against control products (Gutierrez-Adan et al. 2000).

A further modification is Real-time PCR which detects mRNA during the exponential phase of amplification and avoids the necessity for subsequent gel analysis (Bustin et al. 2005). The assay uses unique florescent reporters (Molecular beacons (Marras et al. 2006), SYBR Green (Morrison et al. 1998) and TaqMan probes (Heid et al. 1996)), which emit signals in direct proportion to the PCR product during each round of amplification. While care must be taken to optimize both the RNA isolation and RT-PCR conditions, it is possible to detect as few as 400 copies of mRNA (Gibson et al. 1996). Internal, exogenous RNA (rabbit globin) and endogenous RNA standards (GAPDH, B-actin and rRNA) are required during the amplification process to normalize the RNA levels and to justify the observed variations. The application, including use of various primers, detection limitations and benefits of each of the different systems have been described in detail (Lechniak 2002; Wrenzycki et al. 2004).

Microarray for analysis of gene expression

The combination and convergence of a variety of technologies led to the development of microarrays in the 1990s. This technology is being continually refined and its widespread adoption has indicated that DNA microarrays are to become the main technological workhorse for gene expression studies (Barrett \& Kawasaki 2003; Kunz et al. 2004; Taylor et al. 2004; Ginsberg 2005). The sensitivity of the assay is high, with reports suggesting that this methodological approach is sensitive enough to detect the presence of one mRNA copy per cell (Barrett \& Kawasaki 2003).

The sequencing of the $>3$ billion nucleotides in the human genome, and its extensive characterization suggest it is comprised of approximately $30,000-40,000$ genes. This wealth of genomic information permits researchers to study thousands of genes simultaneously in the cell or tissue type of choice. Subsequently, the (micro) genomic revolution of sequencing is being extended to many different species, including the bovine (see Bovine genome sequencing project paragraph thereafter). Several microarray platforms (see Table 2) are highly suited to the study of gene expression in the bovine preimplantation embryo. Of note are the cDNA arrays (robotic printing), Short Oligonucleotides (25 bases, in situ synthesis) and Long Oligonucleotide arrays (40-80 base pairs, in situ synthesis and robotic printing) (Barrett \& Kawasaki 2003).

The release of the bovine draft sequence and genome assembly has enabled the recent development of high-quality bovine SNP marker arrays to map quantitative trait loci (QTLs) which will result in a tool of significant value to cattle breeding. DNA differences detected through genotyping will expand gene discovery for better meat and milk quality and production, disease susceptibility and the discovery of elements responsible for phenotypic variation, growth and development. With further development it is likely to be applicable to elucidating the relationships between different populations of embryos.

While the application of microarray technologies continues to increase exponentially, it is perhaps cautionary to note that few attempts have been made to replicate and/or compare mRNA data across different platforms. In fact, some comparative cross-platform (and interplatform) analyses show considerable variations between analyses of the same tissue (Kothapalli et al. 2002; Kuo et al. 2002). In addition, other methods (RT-PCR etc) have not been used to confirm results. In an effort to address the standardization of both experiments and controls, guidelines have been published to reduce confusion surrounding interpretation and replication of microarray data (Brazma et al. 2001; Ball et al. 2002; Stoeckert et al. 2002). 
Bovine genome sequencing projecl

The bovine sequencing project is an international effort to sequence the genome of the cow (Bos taurus). The bovine genome is similar in size to the genomes of humans and other mammals, containing approximately 3 billion DNA base pairs (Gibbs et al. 2004).

The collaboration aims to produce a 15-fold coverage of the bovine genome and allow detailed tracking of the DNA differences between a number of cattle breeds to assist discovery of traits for better meat and milk production and to model human disease. The first draft of the bovine genome sequence has been deposited into free public databases for use by biomedical and agricultural researchers around the globe (GenBank (www.ncbi.nih.gov/Genbank) at NIH's National Center for Biotechnology Information (NCBI), EMBL Bank (www.ebi.ac.uk/embl/ index.html) at the European Molecular Biology Laboratory's Nucleotide Sequence Database and the DNA Data Bank of Japan (www.ddbj.nig.ac.jp).

\section{Global Gene Expression using cDNA microarray technology}

The wealth of sequence data will allow researchers to capitalize on gene expression studies through the flexibility in choosing appropriate and specific arrays (Kurimoto et al. 2006; Vige et al. 2006). The utility of the microarray platform in preimplantation embryonic development has recently been demonstrated in both the mouse and bovine.

In the mouse, global changes in gene expression during folliculogenesis (primordial to large antral follicles) were examined for pathways that accompany the acquisition of meiotic and developmental competence (Hosack et al. 2003). The highest degree of up-regulation and down-regulation of gene expression (one third of transcripts exhibited a two fold change in relative abundance) was observed between the primordial to primary follicle transition (Pan et al. 2005). Subsequent transitions were about 10 -fold less. Of particular interest in the primordial to primary follicle transition, was the increased or decreased transcriptional activity of specific regions (predominantly) on selected chromosomes. A phenomenon not observed at later stages of oocyte or embryo development.

The changes in global patterns of gene expression during in vitro maturation of an oocyte from either a primordial or secondary follicle stage displayed only a $4 \%$ and $2 \%$ difference when compared to the in vivo counterparts, respectively. Additional findings revealed an overrepresentation of genes involved in transcription of the commonly mis-expressed genes (1\%) (Pan et al. 2005).

Global patterns of gene expression that surround the development of preimplantation mouse embryos have been examined with cDNA microarrays (Hamatani et al. 2004; Rinaudo \& Schultz 2004; Zeng et al. 2004; Wang S. et al. 2005; Zeng \& Schultz 2005). Results have confirmed previous analyses showing similarities between oocytes and 1-cell embryos, most likely due to the inheritance of mRNA from the oocyte, with major reprogramming of gene expression associated with maternal to embryonic transition and a period of mid-preimplantation gene activation, which precedes the dynamic morphological and functional changes that occur between the morula and blastocyst stage of development (Hamatani et al. 2004). Further analyses during this maternal to embryonic transition revealed a network of genes associated with $\mathrm{Myc}$ and its role in genome activation and reprogramming of gene expression, and $\mathrm{Hdac} 1$ role in the repression of gene expression through chromatin-mediated changes (Zeng et al. 2004; Zeng \& Schultz 2005), Global gene expression patterns in preimplantation embryos have been altered by the type of culture medium. Microarray analysis has shown that genes involved in protein synthesis, cell proliferation and transporter function are down-regulated as a consequence of exposure to in vitro culture medium (Rinaudo \& Schultz 2004; Wang et al. 2005). 
Microarray analyses have been applied to bovine embryo development (Sirard et al. 2005) and recently a 7872 bovine cDNA microarray was use to compare the global gene expression profiles of individual bovine SCNT blastocyst with their donor (somatic) cell and embryos derived from IVF and artificial insemination. The gene expression profile of an individual SCNT blastocyst indicated that it had undergone significant nuclear reprogramming from its original somatic profile (donor cell) so that it unexpectedly resembled a naturally fertilized $\mathrm{Al}$ embryo, more so than IVF embryo. Further analysis is required as to whether the consequence of early-stage reprogramming errors ( $1 \%$ of genes examined) have significant downstream effects to embryonic and fetal development (Smith et al. 2005). Another more recent study comparing IVF and SCNT blastocysts across 5000 cDNAs could only detect a difference in expression of KRT18, and SLC16A1. Further examination of transcript levels could not distinguish an NT from an IVF embryo. The unpredictability of gene expression on a global background of multiple gene expression changes argues for a predominantly stochastic nature of reprogramming errors (Somers et al. 2006). The dynamic changes during global activation of the embryonic genome have been recently examined using the Affymetrix bovine-specific DNA microarray. In the MII oocytes, genes controlling DNA methylation and metabolism were up-regulated. While during embryonic genomic activation (8-cell), those genes essential to the regulation of transcriptoin, chromatin-structure adhesion and signal transduction were up-regulated. Changes in gene expression during these critical development time points is expected to provide unique chromatin structures that maintain totipotency during embryogenesis and permit lineage-specific differentiation during post-implantation development. The consequence of this dynamics has many implications for a number of assisted reproductive technologies (Misirlioglu et al. 2006).

\section{Future developments}

While techniques that detect aberrant gene expression at the level of RNA in the single embryo continue to improve, little is known of the consequence at the level of the proteome. There is a need to develop diagnostic non-destructive solutions that permit the selection of viable embryos following in vitro culture and assisted reproductive techniques (ie Somatic Cell Nuclear Transfer). Several promising strategies are emerging and their application in cell biology is eagerly awaited. Of particular note is the development of fluorescent techniques that may enable researchers to determine the functions of proteins in individual cells.

Traditionally, florescent organic dyes conjugated with antibodies to the protein of interest have allowed imaging of biological events in individual fixed and permeabilized cells. However, new classes of florescent probes have been developed from synergistic developments in molecular biology, organic chemistry and material science that permit multiple functional analyses (gene expression, protein trafficking, biochemical signals) in single cells using non destructive imaging without significantly perturbing endogenous protein function (Giepmans et al. 2006). Two techniques amongst others could be compatible with protein expression studies in the oocyte and developing embryo.

Quantum dots (QD) are inorganic nanocrystals with intense and sustained fluorescence at specific wavelengths, Specialized coatings have made QD water soluble (to prevent quenching) and allow conjugation of protein targeting molecules (antibodies). The final size (QD + biomolecule) prevents easy transport across intact cellular membranes, limiting application to permeabilized cells or extracellular or endocytosed proteins. Further refinements addressing the size limitation using single-molecule optoelectronics have also now been developed (Lee et al. 2005). 
Genetic Tagging or the construction of genetically encoded fluorophores covalently fused to specific cytoplasmic or surface proteins by spontaneous attachment or enzyme ligation also show potential for biological application. The most developed is the tetracysteine-biarsenical system which modifies a target protein to identify it from the many other proteins inside live cells. This specific protein is then fluorescently stained by membrane permeable non-fluorescent dye molecules that attach with picomolar affinity (Griffin et al. 1998). Small dithiol antidotes are added simultaneously to reduce binding, toxicity and perturbations to endogenous proteins and their function (Martin et al. 2005).

Various modifications to these fluorescent approaches have allowed the study of single proteins or complex endogenous pathways of proteins in a single cell (Sachs et al. 2005), protein localization, diffusion and trafficking (Lidke et al. 2004), dynamic and conformational changes in spatiotemporal resolution (Wallrabe \& Periasamy 2005), protein-protein interactions (Gaietta et al. 2002), and by using Chromophore-activated light inactivation (CALI) to inactivate a protein with greater spatiotemporal control than possible with genetic KO or RNA interference approaches (Jay \& Sakurai 1999).

\section{Conclusions}

In the bovine, as in the mouse and other species, the developmental competence of the preimplantation embryo can be influenced by the environment to which it is exposed. While it is capable of tolerating various sub-optimal conditions, the timing and severity of aberrant gene expression can initiate a range of downstream consequences for fetal and postnatal growth and development. Two critical conditions affect the severity of gene expression. They are the inherent quality of the oocyte which affects its ability to fertilise and form a blastocyst and in vitro culture effects which may impair the quality of the blastocyst. The integration of new and emerging genomic technologies allows researchers to profile the transcription patterns of thousands of genes in single oocytes and embryos following in vitro maturation, fertilization, manipulation and culture. Microarray analyses, when properly standardized, will provide unprecedented levels of information at the molecular level and offer greater opportunity to elucidate the requirements necessary for developmentally competent oocytes and/or embryos. In addition, the availability of new non-invasive florescent technologies that permit the examination of proteins endogenous pathway is eagerly awaited. The potential benefits arising from this knowledge include the ability to select viable embryos using non-invasive, quantitative assays of markers for developmental competence and ultimately the manufacture of in vitro culture conditions that properly mimic the correct temporal and spatial expression of a cohort of developmental genes in a manner similar to that seen in vivo.

\section{References}

Auboeuf D \& Vidal H 1997 The use of the reverse transcription-competilive polymerase chain reaction to investigate the in vivo regulation of gene expression in small tissue samples. Analytical Biochemistry 245 141-148.

Avery B, Jorgensen CB, Madison V \& Greve T 1992 Morphological development and sex of bovine in vitro-fertilized embryos. Molecular Reproduction and Development 32 265-270.

Ball CA, Sherlock G, Parkinson H, Rocca-Sera P, Brooksbank C, Causton HC, Cavalieri D,
Gaasterland T, Hingamp P, Holstege F et al. 2002 Standards for microarray data. Science 298539.

Barrett JC \& Kawasaki ES 2003 Microarrays: the use of oligonucleotides and CDNA for the analysis of gene expression. Drug Discovery Today 8 134-141.

Bertolini M, Beam SW, Shim H, Bertolini IR, Moyer AL, Famula TR \& Anderson GB 2002 Growth, development, and gene expression by in vivo- and in vitro-produced day 7 and 16 bovine embryos. Molecular Reproduction and Development $63318-328$.

Bilodeau-Goeseels S \& Schultz GA 1997 Changes in 
The relative abundance of various housekeeping gene transcripts in in vitro-produced early bovine embryos. Molecular Reproduction and Development 47 413-420.

Blanchard AP \& Hood L 1996 Sequence to array; probing the genome's secrels. Nature Biotechnology 14 1649.

Blondin P, Farin PW, Crosier AE, Alexander JE \& Farin CE 2000 In vitro production of embryos alters levels of insulin-like growth factor-II messenger ribonucleic acid in bovine fetuses 63 days after transfer. Biology of Reproduction 62 384-389.

Bourc'his D, Le Bourhis D, Patin D, Niveleau A, Comizzoli P, Renard JP \& Viegas-Pequignot E 2001 Delayed and incomplete reprogramming of chromosome methylation patterns in bovine cloned embryos. Current Biology 11 1542-1546.

Brazma A, Hingamp P, Quackenbush J, Sherlock G, Spellman P, Stoeckert C, Aach J, Ansorge W, Ball CA, Causton $\mathrm{HC}$ et al. 2001 Minimum information about a microarray experiment (MIAME)-toward standards for microarray data. Nature Genetics 29365 371.

Brevini TA, Cillo F, Colleoni S, Lazzari G, Galli C \& Gandolfi F 2004 Expression pattern of the maternal factor zygote arrest 1 (Zar1) in bovine tissues, oocytes, and embryos. Molecular Reproduction and Development 69 375-380.

Bustin SA, Benes V, Nolan T \& Pfaffl MW 2005 Quantitative real-time RT-PCR-a perspective. Journal of Molecular Endocrinology 34 597-601.

Comizzoli P, Uner F, Sakkas D \& Renard JP 2003 Upregulation of glucose metabolism during male pronucleus formation determines the early onset of the $s$ phase in bovine zygotes. Biology of Reproduction 68 1934-1940.

Corcoran D, Fair T \& Lonergan P 2005 Predicting embryo quality: mRNA expression and the preimplantation embryo. Reproductive Biomedicine Online 11 340-348.

Corcoran D, Fair T, Park S, Rizos D, Patel OV, Smith GW, Coussens PM, Ireland J, Boland MP, Evans AC \& Lonergan P 2006 Suppressed expression of genes involved in transcription and translation in in vitro compared with in vivo cultured bovine embryos. Reproduction 131 651-660.

Daniels R, Hall V \& Trounson AO 2000 Analysis of gene transcription in bovine nuclear transfer embryos reconstructed with granulosa cell nuclei. Biology of Reproduction 63 1034-1040.

Daniels R, Hall VJ, French AJ, Korfiatis NA \& Trounson AO 2001 Comparison of gene transcription in cloned bovine embryos produced by different nuclear transfer techniques. Molecular Reproduction and Development 60 281-288.

Davidson E 1986. Gene activity in early development, New York: Academic Press.

de Loos F, van Maurik P, van Beneden T \& Kruip TA 1992 Structural aspects of bovine oocyle maturation in vitro. Molecular Reproduction and Development $31208-214$.
De Sousa PA, Caveney A, Westhusin ME \& Watson AJ 1998a Temporal patterns of embryonic gene expression and their dependence on oogenetic fac tors. Theriogenology 49 115-128.

De Sousa PA, Watson AJ, Schultz GA \& BilodeauGoeseels S $1998 b$ Oogenetic and zygotic gene expression directing early bovine embryogenesis: a review. Molecular Reproduction and Development 51 112-121.

De Sousa PA, Westhusin ME \& Watson AJ 1998c Analy sis of variation in relative $m R N A$ abundance for specific gene transcripts in single bovine oocytes and early embryos. Molecular Reproduction and Development 49 119-130.

Dode MA, Dufort I, Massicotte L \& Sirard MA 2006 Quantitative expression of candidate genes for developmental competence in bovine two-cell embryos. Molecular Reproduction and Development 73 288-297.

Duggan DJ, Bittner $M$, Chen $\mathrm{Y}$, Meltzer P \& Trent IM 1999 Expression profiling using cDNA microarrays. Nature Genetics 21 10.14.

Eckert J \& Niemann H 1998 mRNA expression of leukaemia inhibitory factor (LIF) and its receptor subunits glycoprotein 130 and LIF-receptor-bela in bovine embryos derived in vitro or in vivo. Molecular Human Reproduction 4 957-965.

Enright BP, Lonergan P, Dinnyes A, Fair T, Ward FA, Yang X \& Boland MP 2000 Culture of in vitro produced bovine zygotes in vitro vs in viva: implications for early embryo development and quality. Theriogenology 54 659-673.

Farin PW, Piedrahita JA \& Farin CE 2006 Errors in development of fetuses and placentas from in vitroproduced bovine embryos. Theriogenology 65178 191.

Fernandez-Gonzalez R, Moreira P, Bilbao A, Jimenez A, Perez-Crespo M, Ramirez MA, Rodriguez De Fonseca F, Pintado B \& Gutierrez-Adan A 2004 Long-term effect of in vitro culture of mouse embryos with serum on mRNA expression of imprinting genes, development, and behavior. Proceedings of the National Academy of Sciences of the United States of America 101 5880-5885.

Gaietta G, Deerinck TJ, Adams SR, Bouwer J, Tour O, Laird DW, Sosinsky GE, Tsien RY \& Ellisman MH 2002 Multicolor and electron microscopic imaging of connexin trafficking. Science 296 503-507.

Gibbs R, Weinstock G, Kappes S, Schook L, Skow L \& Womack I 2004 Bovine Genomic Sequencing Initiative - Cattle-izing the Human Genome.

Gibson UE, Heid CA \& Williams PM 1996 A novel method for real time quantitative RT-PCR. Genome Research 6 995-1001.

Giepmans BN, Adams SR, Ellisman MH \& Tsien RY 2006 The fluorescent toolbox for assessing protein location and function. Science 312 217-224.

Gilliland G, Perrin S, Blanchard K \& Bunn HF 1990 Analysis of cylokine mRNA and DNA: delection and quantitation by competitive polymerase chain reaction. Proceedings of the National Academy of Sci- 
ences of the United States of America 872725 2729.

Ginsberg SD 2005 RNA amplification strategies for small sample populations. Methods 37 229.237.

Griffin BA, Adams SR \& Tsien RY 1998 Specific covalent labeling of recombinant protein molecules inside live cells. Science 281 269-272.

Gutierrez-Adan A, Oter M, Martinez-Madrid B, Pintado B \& De La Fuente J 2000 Differential expression of two genes located on the $X$ chromosome between male and female in vitro-produced bovine embryos at the blastocyst stage. Molecular Reproduction and Development 55 146-151.

Gutierrez-Adan A, Lonergan P, Rizos D, Ward FA, Boland MP, Pintado B \& de la Fuente J 2001 Effect of the in vitro culture system on the kinetics of blastocyst development and sex ratio of bovine embryos. Theriogenology 55 1117-1126.

Hall V], Cooney MA, Shanahan P, Tecirlioglu RT, Ruddock NT \& French A) 2005 a Nuclear lamin antigen and messenger RNA expression in bovine in vitro produced and nuclear transfer embryos. Molecular Reproduction and Development 72 471-482.

Hall VJ, Ruddock NT \& French AJ 2005b Expression profiling of genes crucial for placental and preimplantation development in bovine in vivo, in vitro, and nuclear transfer blastocysts. Molecular Reproduction and Development 72 16-24.

Hamatani T, Carter MG, Sharov AA \& Ko MS 2004 Dynamics of global gene expression changes during mouse preimplantation development. Developmental Cell 6 117-131.

Hasler JF 2001 Factors affecting frozen and fresh embryo transfer pregnancy rates in cattle. Theriogenology 56 1401-1415.

Heid CA, Stevens J, Livak KJ \& Williams PM 1996 Real time quantitative PCR. Genome Research 6986 994.

Holm P, Walker SK \& Seamark RF 1996 Embryo viability, duration of gestation and birth weight in sheep after transfer of in vitro matured and in vitro fertilized zygotes cultured in vitro or in vivo. Journal of Reproduction and Fertility 107 175-181.

Holm P \& Callesen H 1998 In vivo versus in vitro produced bovine ova: similarities and differences relevant for practical application. Reproduction, Nutrition, Development 38 579-594.

Holm P, Booth PJ \& Callesen H 2003 Developmental kinetics of bovine nuclear transfer and parthenoge nelic embryos. Cloning and Stem Cells 5 133-142.

Hosack DA, Dennis G, Jr., Sherman BT, Lane HC \& Lempicki RA 2003 Identifying biological themes within lists of genes with EASE. Cenome Biology 4 R70.

Hughes TR \& Shoemaker DD 2001 DNA microarrays for expression profiling. Current Opinion in Chemical Biology 5 21-25.

Humpherys D, Eggan K, Akutsu H, Hochedlinger K, Rideout WM, 3rd, Biniszkiewicz D, Yanagimachi R \& Jaenisch R 2001 Epigenetic instability in ES cells and cloned mice. Science 293 95-97.
Hyttel P 2001 Nucleolus formation in pre-implantation cattle and swine embryos. Italian Journal of Anatomy and Embryology 106 109-717.

lay DG \& Sakurai T 1999 Chromophore-assisted laser inactivation (CALI) to elucidate cellular mechanisms of cancer. Biochimica et Biophysica Acta 1424 M3948.

Jin L \& Lloyd RV 1997 In situ hybridization: methods and applications. Journal of Clinical Laboratory Analysis 11 2-9.

Khurana NK \& Niemann H 2000 Effects of oocyle quality, oxygen tension, embryo density, cumulus cells and energy substrates on cleavage and morula/blastocyst formation of bovine embryos. Theriogenology $54741-756$.

Knijn HM, Wrenzycki C, Hendriksen PJ, Vos PL, Zeinstra EC, van der Weijden GC, Niemann $\mathbf{H}$ \& Dieleman Sj $2005 \mathrm{In}$ vitro and in vivo culture effects on mRNA expression of genes involved in metabolism and apoptosis in bovine embryo5. Reproduction, Fertility, and Development $17775-784$.

Knowles BB, Evsikov AV, de Vries WN, Peaston AE \& Solter D 2003 Molecular control of the oocyte to embryo transition. Philosophical Transactions of the Royal Society of London. Series B, Biological Sciences 358 1381-1387.

Kothapalli R, Yoder SJ, Mane S \& Loughran TP, Jr 2002 Microarray results: how accurate are they? BMC Bioinformatics 322.

Kunz M, Ibrahim SM, Koczan D, Scheid S, Thiesen HJ \& Gross G 2004 DNA microarray technology and its applications in dermatology. Experimental Dermatology 13 593-606.

Kuo WP, Jenssen TK, Butte AJ, Ohno-Machado L \& Kohane IS 2002 Analysis of matched mRNA measurements from two different microarray technologies. Bioinformatics 18 405-412.

Kurimoto K, Yabuta Y, Ohinata $Y$, Ono $Y$, Uno KD, Yamada RG, Ueda HR \& Saitou M 2006 An improved single-cell CDNA amplification method for efficient high-density oligonucleotide microarray analysis. Nucleic Acids Research 34 e42.

Kurosaka S, Eckardt S \& Mclaughlin KJ 2004 Pluripotent lineage definition in bovine embryos by $0 \mathrm{ct} 4$ transcript localization. Biology of Reproduction 71 1578-1582.

Lazzari G, Wrenzycki C, Herrmann D, Duchi R, Kruip T, Niemann H \& Galli C 2002 Cellular and molecular deviations in bovine in vilro-produced embryos are related to the large offspring syndrome. Biology of Reproduction 67 767-775.

Lechniak D 2002 Quantitative aspect of gene expression analysis in mammalian oocyles and embryos. Reproductive Biology 2 229-241.

Lee TH, Gonzalez II, Zheng J \& Dickson RM 2005 Single-molecule optoelectronics. Accounts of Chemical Research 38 534-541.

Leibfried L \& First NL 1979 Characterization of bovine follicular oocytes and their ability to mature in vitro, Journal of Animal Science $\mathbf{4 8}$ 76-86.

Li X, Amarnath D, Kato Y \& Tsunoda Y 2006 Analysis 
of development-related gene expression in cloned bovine blastocysts with different developmental potential. Cloning and Stem Cells 8 41-50.

Lidke DS, Nagy P, Heintzmann R, Arndt-Jovin DJ, Post JN, Grecco HE, Jares-Erijman EA \& Jovin TM 2004 Quantum dot ligands provide new insights into erbB/HER receptor-mediated signal transduction. Nature Biotechnology 22 198-203.

Lindner GM \& Wright RW, Jr 1983 Bovine embryo morphology and evaluation. Theriogenology 20407 . 416.

Lonergan P, Gutierrez-Adan A, Pintado B, Fair T, Ward F, Fuente JD \& Boland M 2000 Relationship be tween time of first cleavage and the expression of IGF-I growth factor, its receptor, and two housekeeping genes in bovine two-cell embryos and blas. tocysts produced in vitro. Molecular Reproduction and Development 57 146-152.

Lonergan P, Rizos D, Ward F \& Boland MP 2001 Factors influencing oocyte and embryo quality in cattle. Reproduction, Nutrition, Development 41 427-437.

Lonergan P, Rizos D, Gutierrez-Adan A, Fair T \& Boland MP 2003a Oocyte and embryo quality: effect of origin, culture conditions and gene expression patterns. Reproduction in Domestic Animals 38 259-267.

Lonergan P, Rizos D, Kanka J, Nemcova L, Mbaye AM, Kingston M, Wade M, Duffy P \& Boland MP $2003 \mathrm{~b}$ Temporal sensitivity of bovine embryos to culture environment after fertilization and the implications for blastocyst quality. Reproduction 126337 346.

Lonergan P, Fair T, Corcoran D \& Evans AC 2006 Effect of culture environment on gene expression and developmental characteristics in IVF-derived embryos. Theriogenology 65 137-152.

Lou XI, Schena M, Horrigan FT, Lawn RM \& Davis RW 2001 Expression monitoring using CDNA microarrays. A general protocol. Methods in Molecular Biology 175 323-340.

Marras SA, Tyagi S \& Kramer FR 2006 Real-time assays with molecular beacons and other fluorescent nucleic acid hybridization probes. Clinica Chimica Acta 363 48-60.

Martin BR, Giepmans BN, Adams SR \& Isien RY 2005 Mammalian cell-based optimization of the biarsenical-binding tetracysteine motif for improved fluorescence and affinity. Nature Biotechnology 23 1308-1314.

Memili E \& First NL 2000 Zygotic and embryonic gene expression in cow: a review of timing and mechanisms of early gene expression as compared with other species. Zygote 8 87-96.

Miller DJ, Eckert J), Lazzari G, Duranthon-Richoux V, Sreenan J, Morris D, Galli C, Renard JP \& Fleming TP 2003 Tight junction messenger RNA expression levels in bovine embryos are dependent upon the ability to compact and in vitro culture methods. Biology of Reproduction 68 1394-1402.

Milligan L, Forne T, Antoine E, Weber M, Hemonnot B, Dandolo L, Brunel C \& Cathala G 2002 Turn- over of primary transcripts is a major step in the regulation of mouse $\mathrm{H} 19$ gene expression. EMBO Reports 3 774-779.

Misirlioglu M, Page GP, Sagirkaya H, Kaya A, Parrish IJ, First NL \& Memili E 2006 Dynamics of global transcriptome in bovine mature oocytes and preimplantation embryos. Proceedings of the National Academy of Sciences of the United States of America 103 18905-18910.

Morrison TB, Weis IJ \& Wittwer CT 1998 Quantification of low-copy transcripts by continuous SYBR Green I monitoring during amplification. BioTechniques 24 954-958, 960, 962.

Nicoletti A \& Sassy-Prigent C 1996 An alternative quantitative polymerase chain reaction method. Analytical Biochemistry 236 229-241.

Niemann H \& Wrenzycki C 2000 Alterations of expression of developmentally important genes in preimplantation bovine embryos by in vitro culture conditions: implications for subsequent development. Theriogenology 53 21-34.

Niemann $H$, Wrenzycki C, Lucas-Hahn A, Brambrink T, Kues WA \& Carnwath JW 2002 Gene expression patterns in bovine in vitro-produced and nuclear transfer-derived embryos and their implications for early development. Cloning and Stem Cells 429 . 38.

Oliveira AT, Lopes RF \& Rodrigues JL 2006 Gene expression and developmental competence of bovine embryos produced in vitro with different serum concentrations. Reproduction in Domestic Animals 41 $129-136$.

Pan $\mathrm{H}, \mathrm{O}^{\prime}$ Brien $\mathrm{M}$ J, Wigglesworth K, Eppig J \& Schultz RM 2005 Transcript profiling during mouse oocyte development and the effect of gonadotropin priming and development in vitro. Developmental Biology 286 493-506.

Pennetier S, Uzbekova S, Perreau C, Papillier P, Mermillod P \& Dalbies-Tran R 2004 Spatio-temporal expression of the germ cell marker genes MATER, ZAR1, GDF9, BMP15, andVASA in adult bovine tissues, oocytes, and preimplantation embryos. Biology of Reproduction 71 1359-1366.

Prediger EA 2001 Detection and quantitation of mRNAs using ribonuclease protection assays. Methods in Molecular Biology 160 495-505.

Reichenbach HD, Liebrich J, Berg U \& Brem G 1992 Pregnancy rates and births after unilateral or bilateral transfer of bovine embryos produced in vitro. Journal of Reproduction and Fertility 95 363-370.

Reik W, Dean W \& Walter J 2001 Epigenetic reprogramming in mammalian development. Science 293 1089-1093.

Renard JP, Chastant S, Chesne P, Richard C, Marchal I, Cordonnier N, Chavatte P \& Vignon X 1999 Lymphoid hypoplasia and somalic cloning. Lancet 353 1489-1491.

Rinaudo P \& Schultz RM 2004 Effects of embryo culture on global pattern of gene expression in preimplantation mouse embryos. Reproduction 128301 311. 
Rizos D, Lonergan P, Boland MP, Arroyo-Garcia R, Pintado B, de la Fuente J \& Gutierrez-Adan A 2002a Analysis of differential messenger RNA expression between bovine blastocysts produced in different culture systems: implications for blastocyst quality. Biology of Reproduction 66 589-595.

Rizos D, Ward F, Duffy P, Boland MP \& Lonergan P $2002 \mathrm{~b}$ Consequences of bovine oocyle maturation, fertilization or early embryo development in vitro versus in vivo: implications for blastocyst yield and blastocysi quality. Molecular Reproduction and Development 61 234-248.

Rizos D, Gutierrez-Adan A, Perez-Garnelo S, De La Fuente J, Boland MP \& Lonergan P 2003 Bovine embryo culture in the presence or absence of serum: implications for blastocyst development, cryololerance, and messenger RNA expression. Biology of Reproduction 68 236-243.

Rizos D, Gutierrez-Adan A, Moreira P, O'Meara C, Fair T, Evans AC, Boland MP \& Lonergan P 2004 Species-related differences in blastocyst quality are associated with differences in relative mRNA Iranscription. Molecular Reproduction and Development $69381-386$.

Ruddock NT, Wilson KI, Cooney MA, Korfiatis NA, Tecirlioglu RT \& French Al 2004 Analysis of imprinted messenger RNA expression during bovine preimplantation development. Biology of Reproduction 70 1131-1135.

Sachs K, Perez O, Pe'er D, Lauffenburger DA \& Nolan GP 2005 Causal protein-signaling networks derived from multiparameter single-cell data. Science 308 $523-529$.

Saric T \& Sydney AS 1997 Semiquantitive RT-PCR: enhancement of assay accuracy and reproducibility. Bio Techniques 22 630-636.

Sinclair KD, Young LE, Wilmut I \& McEvoy TG 2000 In-utero overgrowth in ruminants following embryo culture: lessons from mice and a warning to men. Human Reproduction 15 Supplement 5 68-86.

Sirard MA, Dufort I, Vallee M, Massicotte L, Gravel C, Reghenas $\mathbf{H}$, Watson AJ, King WA \& Robert $C$ 2005 Potential and limitations of bovine-specific arrays for the analysis of mRNA levels in early development: preliminary analysis using a bovine embryonic array. Reproduction, Fertility, and Development 17 47-57.

Smith SL, Everts RE, Tian XC, Du F, Sung $L Y$, Rodriguez-Zas SL, leong BS, Renard JP, Lewin HA \& Yang X 2005 Global gene expression profiles reveal significant nuclear reprogramming by the blastocyst stage after cloning. Proceedings of the $\mathrm{Na}$ tional Academy of Sciences of the United States of America 102 17582-17587.

Somers J, Smith C, Donnison M, Wells DN, Henderson H, Mcleay L \& Pfeffer PL 2006 Gene expression profiling of individual bovine nuclear transfer blastocysts. Reproduction 131 1073-1084.

Stanton JA, Macgregor AB \& Green DP 2003 Gene expression in the mouse preimplantation embryo. Reproduction 125 457-468.
Stoeckert CJ, Jr., Causton HC \& Ball CA 2002 Microarray databases: standards and ontologies. Nature Cenetics 32 Supplement 469-473.

Taylor TB, Nambiar PR, Raja R, Cheung E, Rosenberg DW \& Anderegg B 2004 Microgenomics: Identification of new expression profiles via small and singlecell sample analyses. Cytometry A 59 254-261.

Thompson JG 1997 Comparison between in vivo-derived and in vitro-produced pre-elongation embryos from domestic ruminants. Reproduction, Fertility, and Development 9 341-354.

Thompson IG 2000 In vitro culture and embryo metabolism of cattle and sheep embryos - a decade of achievement. Animal Reproduction Science 60-61 263-275.

Tremblay K, Vigneault C, McGraw S, Morin G \& Sirard MA 2006 Identification and characlerization of a novel bovine oocyte-specific secreted protein gene. Gene 2929.

Vige A, Gallou-Kabani C, Gross MS, Fabre A, Junien C \& Jais JP 2006 An oligonucleolide microarray for mouse imprinted genes profiling. Cytogenetic and Genome Research 113 253-261.

Wallrabe H \& Periasamy A 2005 Imaging prolein molecules using FRET and FLIMI microscopy. Current Opinion in Biotechnology 16 19-27.

Wang H \& Dey SK 2006 Roadmap to embryo implantation: clues from mouse models. Nature Reviews. Genetics 7 185-199.

Wrenzycki C \& Niemann H 2003 Epigenetic reprogramming in early embryonic development: effects of in-vitro production and somatic nuclear transfer. Reproductive Biomedicine Online 7 649-656.

Wang S, Cowan CA, Chipperfield H \& Powers RD 2005 Gene expression in the preimplantation embryo: in-vitro developmental changes. Reproductive Biomedicine Online 10 607-616.

Ward F, Rizos D, Corridan D, Quinn K, Boland M \& Lonergan P 2001 Palernal influence on the time of first embryonic cleavage post insemination and the implications for subsequent bovine embryo development in vitro and fertility in vivo. Molecular Reproduction and Development 60 47-55.

Watson AJ, De Sousa P, Caveney A, Barcroft LC, Natale D, Urquhart J \& Westhusin ME 2000 Impact of bovine oocyle maturation media on oocyle transcript levels, blastocyst development, cell number, and apoptosis. Biology of Reproduction 62 355-364.

Winzeler EA, Schena M \& Davis RW 1999 Fluores. cence-based expression monitoring using microarrays. Methods in Enzymology 306 3-18.

Wrenzycki C, Herrmann D, Keskintepe L, Martins A, Jr., Sirisathien S, Brackett B \& Niemann H 2001a Effects of culture system and protein supplementation on mRNA expression in pre-implantation bovine embryos. Human Reproduction 16 893-901.

Wrenzycki C, Wells D, Herrmann D, Miller A, Oliver J. Tervit R \& Niemann H 2001b Nuclear transfer protocol affects messenger RNA expression patterns in cloned bovine blastocysts. Biology of Reproduction 65 309-317. 
Wrenzycki C, Lucas-Hahn A, Herrmann D, Lemme E, Korsawe K \& Niemann H 2002 In vitro production and nuclear transfer affecl dosage compensation of the X-linked gene transcripts. G6PD, PGK, and Xist in preimplantation bovine embryos. Biology of Reproduction 66 127-134.

Wrenzycki C, Hermann D, Lucas-Hahn A, Lemme E, Korsawe K \& Niemann H 2004 Gene expression patterns in in vitro-produced and somatic nuclear transfer-derived preimplantation bovine embryos: relationship to the large offspring syndrome? Antmal Reproduction Science 82-83 593-603.

Wrenzycki C, Herrmann D, Lucas-Hahn A, Gebert C, Korsawe K, Lemme E, Carnwath JW \& Niemann H 2005a Epigenetic reprogramming throughout preimplantation development and consequences for assisted reproductive technologies. Birth Defects Research. Part C, Embryo Today 75 1-9.

Wrenzycki C, Herrmann D, Iucas-Hahn A, Korsawe K, Lemme E \& Niemann H 2005 b Messenger RNA expression patterns in bovine embryos derived from in vitro procedures and their implications for development. Reproduction, Fertility, and Development 17 23-35.

Xu KP, Yadav BR, King WA \& Betteridge KJ 1992 Sexrelated differences in developmental rates of bovine embryos produced and cultured in vitro. Molecular Reproduction and Development 31 249-252.

Yang MY \& Rajamahendran R 2002 Expression of Bcl2 and Bax proteins in relation to quality of bovine oocytes and embryos produced in vitro. Animal Reproduction Science 70 159-169.

Young LE, Sinclair KD \& Wilmut I 1998 Large offspring syndrome in cattle and sheep. Reviews of Reproduction 3 155-163.

Zeng F \& Schultz RM 2005 RNA transcript profiling during zygotic gene activation in the preimplantation mouse embryo. Developmental Biology 283 40-57.

Zeng F, Baldwin DA \& Schultz RM 2004 Transcript profiting during preimplantation mouse development. Developmental Biology 272 483-496. 